(c) American Dairy Science Association, 2005.

\title{
Effects of a Proteolytic Feed Enzyme on Intake, Digestion, Ruminal Fermentation, and Milk Production
}

\author{
J.-S. Eun and K. A. Beauchemin \\ Agriculture and Agri-Food Canada, Research Centre, Lethbridge, Alberta, T1J 4B1, Canada
}

\begin{abstract}
The effects of exogenous proteolytic enzyme (EPE) on intake, digestibility, ruminal fermentation, and lactational performance were determined using 8 lactating Holstein cows in a double $4 \times 4$ Latin square experiment with a $2 \times 2$ factorial arrangement of treatments. Diets based on barley silage and alfalfa hay as the forage sources were formulated to maintain different forage to concentrate ratios [60:40 vs. 34:66, dry matter (DM) basis]. Four dietary treatments were tested: high forage (HF) without EPE (HF-EPE), HF with EPE (HF+EPE), low forage (LF) without EPE (LF-EPE), and LF with $\mathrm{EPE}(\mathrm{LF}+\mathrm{EPE})$. The EPE, which contained proteolytic activity but negligible fibrolytic activity, was added to the concentrate portion of the diets after pelleting at a rate of $1.25 \mathrm{~mL} / \mathrm{kg}$ of DM. Adding EPE to the diet increased total tract digestibilities of DM, organic matter, $\mathrm{N}$, acid detergent fiber, and neutral detergent fiber, with larger increases in digestibility observed for cows fed LF+EPE. Effects of added EPE on in vivo digestibility were consistent with improvements in gas production and degradability of the individual components of the TMR observed in vitro. Ruminal enzymic activities of xylanase and endoglucanase increased with addition of EPE to the diet, which may have accounted for improvements in fiber digestion. However, feeding EPE unexpectedly decreased feed intake of cows, which offset the benefits of improved feed digestibility. Consequently, milk yield of cows fed high or low forage diets decreased with adding EPE. Nevertheless, dairy efficiency, expressed as milk/DM intake, was highest for the LF+EPE diet. Addition of EPE to the diet increased milk fat and milk lactose percentages, but decreased milk protein percentage of cows fed a low forage diet. For cows fed high forage diets, EPE only increased milk lactose percentage. Efficiency of $\mathrm{N}$ use for milk production was decreased for both the high and low forage
\end{abstract}

Received September 2, 2004.

Accepted March 17, 2005.

Corresponding author: Karen A. Beauchemin; e-mail: beauchemin @agr.gc.ca.

*Contribution number (387)0451 of the Lethbridge Research Centre. diets when EPE was added to the diet. Mean ruminal $\mathrm{pH}$ was lowered when EPE was added a low forage diet, likely due to the increased degradation of forage and concentrate, but there was no effect of EPE on rumen $\mathrm{pH}$ when cows were fed high forage diets. Profiles of VFA and microbial yield were not affected by adding EPE to the diets. Adding EPE to a total mixed ration containing alfalfa hay, barley silage, and concentrate improved nutrient digestibility in the total tract, and the response was maximized with a high concentrate diet. However, improvements in digestibility were offset by decreased feed intake, likely due to increased ruminal acidosis.

(Key words: exogenous proteolytic enzyme, forage to concentrate ratio, digestibility, dairy efficiency)

Abbreviation key: ECM = energy-corrected milk, $\mathbf{E P E}=$ exogenous proteolytic enzyme, $\mathbf{H F}=$ high forage diet, HF-EPE = high forage without exogenous proteolytic enzyme, HF+EPE = high forage with exogenous proteolytic enzyme, LF = low forage diet, LF-EPE = low forage without exogenous proteolytic enzyme, $\mathbf{L F}+\mathbf{E P E}=$ low forage with exogenous proteolytic enzyme, $\mathbf{P D}=$ purine derivatives.

\section{INTRODUCTION}

Enzyme research for ruminants has been primarily focused on the efficacy of polysaccharidase enzymes, mainly xylanases and cellulases. The use of exogenous proteolytic enzymes (EPE) has been ignored because it has been assumed they would cause excessive protein degradation in the rumen, resulting in inefficient $\mathrm{N}$ use. Surprisingly, however, 2 in vitro studies recently done in our laboratory (Colombatto et al., 2003a,b) reported large increases in DM and NDF degradability of alfalfa hay and TMR as a result of supplementation with an EPE product that did not contain cellulolytic or xylanolytic activities. Despite a large increase in protease activity in the culture, protein degradation was only numerically increased. This finding motivated us to investigate whether supplemental protease activity would have beneficial effects for lactating dairy cows.

Dry matter intake can be limiting when high-producing dairy cows are fed high forage (HF) diets. Conse- 
quently, low forage (LF) diets are typically fed to cows in early lactation to support high milk production and to minimize negative energy balance. However, feeding LF diets often compromises fiber digestion due to low ruminal $\mathrm{pH}$. The use of EPE was shown to improve fiber digestion at low ruminal $\mathrm{pH}$ (Colombatto et al., 2003a), thus EPE may help overcome the limits to fiber digestion caused by low $\mathrm{pH}$ (Yang et al., 2002). We hypothesized that if EPE increased digestibility of fiber, then DMI and milk production would increase for cows fed HF diets. This would allow dairy producers to feed HF diets, thereby potentially avoiding ruminal acidosis associated with LF diets while maintaining high milk production. Furthermore, we examined if adding EPE to LF diets would help improve fiber digestion, which is typically compromised due to low ruminal $\mathrm{pH}$ and rapid passage rate from the rumen. This study examined the effects of supplementing dairy cow diets containing 2 forage concentrations with an enzyme product containing only protease activity on nutrient intake, digestibility, and milk production and composition. In addition, we assessed whether EPE supplementation affected ruminal microbial fermentation.

\section{MATERIALS AND METHODS}

\section{Cows and Diets}

Eight multiparous lactating Holstein cows were used; 4 cows were surgically fitted with ruminal cannulas. Days in milk ranged from 32 to $76 \mathrm{~d}$ and from 16 to $110 \mathrm{~d}$ for noncannulated and cannulated cows, respectively, at the start of the experiment. Average BW was $690 \pm 44 \mathrm{~kg}$ at the beginning of the experiment and 685 $\pm 40 \mathrm{~kg}$ at the end of the experiment.

The design of the experiment was a double $4 \times 4$ Latin square with each period lasting $21 \mathrm{~d}$ (10 d of treatment adaptation and $11 \mathrm{~d}$ of data collection). The cows were allocated to squares by whether they were surgically cannulated, and the 2 squares were conducted simultaneously. Within square, cows were randomly assigned to a sequence of 4 diets. A $2 \times 2$ factorial arrangement of was used; $\mathrm{HF}$ or LF diet with a forage-to-concentrate ratio of $60: 40$ or 34:66 (DM basis), respectively, was combined without or with EPE to form 4 treatments: $\mathrm{HF}$ without $\mathrm{EPE}(\mathbf{H F}-\mathbf{E P E}), \mathrm{HF}$ with $\mathrm{EPE}(\mathbf{H F}+\mathbf{E P E})$, LF without EPE (LF-EPE), and LF with EPE (LF+EPE) (Table 1).

The forages used were alfalfa hay and barley silage (Table 2). The concentrate contained steam-rolled barley, dry-rolled corn, ground barley, and a pelleted supplement, and the formulation of the concentrate differed for LF and HF diets. The diets were formulated using the Cornell-Penn-Miner System (CPM Dairy, Version 2.0) and balanced to provide sufficient metabo-
Table 1. Ingredient and chemical composition of the diets (DM basis).

\begin{tabular}{|c|c|c|}
\hline \multirow[b]{2}{*}{ Item } & \multicolumn{2}{|c|}{ Diet } \\
\hline & $\begin{array}{l}\text { High } \\
\text { forage } \\
\text { (HF) }\end{array}$ & $\begin{array}{l}\text { Low } \\
\text { forage } \\
\text { (LF) }\end{array}$ \\
\hline \multicolumn{3}{|l|}{ Ingredient, $\%$ of DM } \\
\hline Barley silage & 44.5 & 18.2 \\
\hline Alfalfa hay, chopped & 16.0 & 16.0 \\
\hline Barley, steam rolled & 3.5 & 28.0 \\
\hline Corn, dry rolled & 11.9 & 12.5 \\
\hline Barley, ground ${ }^{1}$ & 3.5 & 3.8 \\
\hline Molasses beet ${ }^{1}$ & 2.5 & 2.6 \\
\hline Beet pulp, ground ${ }^{1}$ & 1.2 & 1.3 \\
\hline Alberta Gold ${ }^{1,2}$ & 3.5 & 3.6 \\
\hline SoyPass 1,3 & 4.2 & 4.5 \\
\hline Corn gluten meal ${ }^{1}$ & 5.0 & 4.8 \\
\hline Dicalcium phosphate $^{1}$ & 0.7 & 0.7 \\
\hline Sodium bicarbonate ${ }^{1}$ & 0.4 & 0.4 \\
\hline Flavoring agent ${ }^{1}$ & 0.01 & 0.01 \\
\hline Soybean oil ${ }^{1}$ & 2.4 & 2.5 \\
\hline Mineral and vitamin premix ${ }^{1,4}$ & 1.0 & 1.1 \\
\hline \multicolumn{3}{|l|}{ Chemical composition, \% of DM } \\
\hline DM, \% & $56.4 \pm 1.3$ & $72.4 \pm 0.8$ \\
\hline $\mathrm{OM}$ & $92.0 \pm 0.7$ & $93.1 \pm 0.7$ \\
\hline $\mathrm{CP}$ & $19.6 \pm 1.2$ & $20.3 \pm 1.3$ \\
\hline NDF & $28.8 \pm 1.7$ & $25.3 \pm 0.9$ \\
\hline $\mathrm{ADF}$ & $14.0 \pm 0.9$ & $11.4 \pm 0.9$ \\
\hline Starch & $26.2 \pm 2.3$ & $31.6 \pm 3.3$ \\
\hline $\mathrm{NE}_{\mathrm{L}}, \mathrm{Mcal} / \mathrm{kg}^{5}$ & 1.62 & 1.78 \\
\hline
\end{tabular}

\footnotetext{
${ }^{1}$ Ingredients that were in the pelleted supplement.

${ }^{2} \mathrm{~A}$ registered trademark for heat-processed canola meal product (Canbra Foods, Lethbridge, AB, Canada).

${ }^{3} \mathrm{~A}$ registered trademark for nonenzymatic browned, dehulled solvent-extracted soybean meal product (LignoTech USA, Inc., Rothschild, WI).

${ }^{4}$ Contained $29.4 \% \mathrm{NaCl}, 1.0 \% \mathrm{ZnSO}_{4}, 1.2 \% \mathrm{MnSO}_{4} \cdot 4 \mathrm{H}_{2} \mathrm{O}, 0.4 \%$ $\mathrm{CuSO}_{4} \cdot 5 \mathrm{H}_{2} \mathrm{O}, 45 \mathrm{mg} / \mathrm{kg} \mathrm{CoSO}{ }_{4} \cdot 5 \mathrm{H}_{2} \mathrm{O}, 44 \mathrm{mg} / \mathrm{kg} \mathrm{Na} \mathrm{SeO}_{3}, 8 \%$ Dynamate (Pitman Moore, Inc., Mundelein, IL; $22 \% \mathrm{~S}, 18 \% \mathrm{~K}$, and $11 \%$ $\mathrm{Mg}), 60 \mathrm{mg} / \mathrm{kg}$ of ethylenediamine dihydroiodide, $680 \mathrm{IU}$ of vitamin $\mathrm{A} / \mathrm{g}, 160 \mathrm{IU}$ of vitamin $\mathrm{D} / \mathrm{g}$, and $2 \mathrm{IU}$ of vitamin $\mathrm{E} / \mathrm{g}$.

${ }^{5}$ Based on tabular value (NRC, 2001).
}

lizable energy and protein, vitamins, and minerals to produce $40 \mathrm{~kg} / \mathrm{d}$ of milk with $3.5 \%$ fat and $3.3 \% \mathrm{CP}$. The proportion of alfalfa hay was maintained at $16 \%$ of the dietary DM for HF and LF diets because in a previous in vitro study (Colombatto et al., 2003b), we observed that proteolytic enzymes were particularly effective for alfalfa hay. By keeping the proportion of alfalfa hay the same in HF and LF diets, effects of forage proportion on enzyme effectiveness were not confounded by level of alfalfa hay. The LF diet was formulated by decreasing the proportion of barley silage and increasing the proportion of concentrate.

The enzyme product, Protex 6L (Genencor International, Rochester, NY), was in liquid form $(128 \mathrm{mg} / \mathrm{mL}$ of protein content) and added at a rate of $1.25 \mathrm{~mL} / \mathrm{kg}$ of DM to the HF and LF diets The rate of enzyme application was selected based on in vitro studies carried out previously (Colombatto et al., 2003a,b). This 
Table 2. Chemical composition of forages and concentrates.

\begin{tabular}{lllllc}
\hline & \multicolumn{2}{c}{ Forages } & & \multicolumn{2}{c}{ Concentrates } \\
\cline { 2 - 3 } Item & Barley silage & Alfalfa hay & & High forage diet & Low forage diet \\
\hline $\mathrm{DM}, \%$ & $38.0 \pm 2.1$ & $92.1 \pm 1.4$ & & $94.5 \pm 0.2$ & $94.4 \pm 0.2$ \\
$\mathrm{OM}, \%$ of DM & $92.5 \pm 0.4$ & $90.2 \pm 0.6$ & & $92.6 \pm 0.4$ & $94.4 \pm 0.2$ \\
$\mathrm{CP}, \%$ of DM & $12.3 \pm 0.5$ & $18.2 \pm 1.1$ & & $23.9 \pm 0.6$ & $21.7 \pm 0.2$ \\
$\mathrm{NDF}, \%$ of DM & $36.1 \pm 1.5$ & $50.0 \pm 2.6$ & & $14.7 \pm 0.6$ & $15.1 \pm 1.2$ \\
ADF, \% of DM & $17.5 \pm 2.2$ & $34.5 \pm 2.2$ & & $6.0 \pm 0.3$ & $5.0 \pm 0.1$ \\
\hline
\end{tabular}

commercial enzyme product is characterized with protease activity derived from a strain of Bacillus licheniformis, compliant with the current specifications for food-grade enzymes. The concentrated (undiluted) enzyme product was sprayed onto the pelleted supplement after it was made. Applying enzymes to feed before ingestion is believed to enhance binding of the enzyme to the feed, thereby increasing the resistance of the enzymes to proteolysis in the rumen (Beauchemin et al., 2004). The presence of substrate is known to increase enzyme resistance to proteolytic inactivation (Fontes et al., 1995). Four concentrates were prepared by combining the pellet with steam-rolled barley and dryrolled corn at the beginning of each period. Concentrates were discarded at the end of each period to ensure that the time between applying EPE to feed and feeding was the same for all treatments.

Diets were fed as a TMR for ad libitum intake with at least $10 \%$ of daily feed refusal. All cows were individually fed 3 times daily at 0600,1200 , and $1800 \mathrm{~h}$ with approximately $10 \%, 50 \%$, and $40 \%$ of total daily feed allocation at each feeding, respectively. Feed offered and refused were measured and recorded daily to determine DMI. Cows had free access to water.

Cows were cared for according to the Canadian Council on Animal Care guidelines (Ottawa, Ontario, Canada). Cows were housed in individual tie stalls fitted with rubber mattresses, bedded with wood shavings, and milked twice daily at 0630 and $1630 \mathrm{~h}$. Milk production was recorded daily throughout the experiment. Cows were turned outside to a dry-lot for exercise for at least $1 \mathrm{~h}$ daily in the morning after being milked, except on days during which total urine was collected from cannulated cows. Milk was sampled during the a.m. and p.m. milkings on 4 consecutive days (d 15 to d 18) in each period. Milk samples were preserved with potassium dichromate and stored at $4^{\circ} \mathrm{C}$ until sent to the Central Alberta Milk Testing Laboratory (Edmonton, Alberta, Canada). Milk was analyzed for fat, CP, lactose, and MUN (AOAC, 1990) using an infrared analyzer (Milk-O-Scan 605; Foss Electric, Hillerød, Denmark). Milk composition was corrected for differences in milk volume between a.m. and p.m. milkings. Yield of energy-corrected milk (ECM) was calculated as follows (Tyrrell and Reid, 1965):

$$
\begin{aligned}
& \text { ECM }, \mathrm{kg} / \mathrm{d}=[(41.63 \times \text { milk fat percentage } \\
& +24.13 \times \text { milk protein percentage }+21.60 \\
& \times \text { milk lactose percentage }-11.72) \\
& \times \text { milk yield }, \mathrm{kg} / \mathrm{d}] / 340 .
\end{aligned}
$$

Cows were weighed at approximately $0830 \mathrm{~h}$ at the beginning and end of each period, and these weights were used to calculate the mean BW of cows for each experimental period.

\section{Feed Sampling}

Barley silage, chopped alfalfa hay, and concentrates were sampled weekly to determine DM content. Diets were adjusted weekly to account for changes in DM content. Samples of the TMR fed and orts for individual cows were collected daily during the data collection period, dried at $55^{\circ} \mathrm{C}$, ground to pass a 1 -mm screen (standard model 4; Arthur H. Thomas Co., Philadelphia, PA), and stored for subsequent analyses.

\section{Digestibility}

Apparent total tract digestion of nutrients was measured using $\mathrm{YbCl}_{3}$ (Rhône-Poulenc, Inc., Shelton, CT) added directly to the pelleted concentrate portion of the feed at a rate of $8.7 \mathrm{~g}$ of $\mathrm{YbCl}_{3} / \mathrm{d}$ per cow to achieve intake of approximately $2 \mathrm{~g}$ of $\mathrm{Yb} / \mathrm{d}$ per cow. Fecal samples (approximately $100 \mathrm{~g}$, wet weight) were collected for all cows from the rectum once or twice daily at various times for $6 \mathrm{~d}$ beginning on $\mathrm{d} 12$. Samples were composited across sampling times for each cow, dried at $55^{\circ} \mathrm{C}$, ground to pass a 1-mm screen (standard model 4), and stored for chemical analysis. Apparent total tract nutrient digestibilities were calculated from concentrations of $\mathrm{Yb}$ and nutrients in diets fed, orts, and feces using the following equation: apparent digestibility $=100-$ $\left[100 \times\left(\mathrm{Yb}_{\mathrm{d}} / \mathrm{Yb}_{\mathrm{f}}\right) \times\left(\mathrm{N}_{\mathrm{f}} / \mathrm{N}_{\mathrm{d}}\right)\right]$, where $\mathrm{Yb}_{\mathrm{d}}=\mathrm{Yb}$ concentration in the diet actually consumed, $\mathrm{Yb}_{\mathrm{f}}=\mathrm{Yb}$ concentration in the feces, $\mathrm{N}_{\mathrm{f}}=$ concentration of the nutrient in the 
feces, and $\mathrm{N}_{\mathrm{d}}=$ concentration of the nutrient in the diet actually consumed.

\section{Ruminal Fermentation and Rumen Contents}

Ruminal contents were sampled from cannulated cows $0,1,2,3,4,5$, and $6 \mathrm{~h}$ after the $1200 \mathrm{~h}$ feeding on $\mathrm{d} 19$ and 20 . Approximately $1 \mathrm{~L}$ of ruminal contents was obtained from the anterior dorsal, anterior ventral, medial ventral, posterior dorsal, and posterior ventral locations within the rumen, composited by cow, and strained through a PECAP polyester screen (pore size $355 \mu \mathrm{m}$; B \& S H Thompson, Ville Mont-Royal, Quebec, Canada). The ruminal $\mathrm{pH}$ of the filtered ruminal fluid was measured within 5 min of collecting the ruminal contents. Five milliliters of the filtered ruminal fluid was added to $1 \mathrm{~mL}$ of $1 \%$ sulfuric acid and samples were retained for ammonia- $\mathrm{N}\left(\mathrm{NH}_{3}-\mathrm{N}\right)$ determination. Another $5 \mathrm{~mL}$ of the filtered ruminal fluid taken at 3 $\mathrm{h}$ after the $1200 \mathrm{~h}$ feeding was added to $1 \mathrm{~mL}$ of $25 \%$ of meta-phosphoric acid and samples were retained for VFA determination.

Rumen evacuation was undertaken with cannulated cows on the final day of each period. All ruminal contents (solid and liquid) that could be removed by hand and plastic cup $(0.25 \mathrm{~L})$ were emptied into a large insulated container and weighed to estimate rumen volume. Samples (approximately $2.5 \mathrm{~kg}$ ) of ruminal contents were taken after mixing to analyze DM content. Ruminal contents were switched between cannulated cows within $1 \mathrm{~h}$ of commencement to facilitate adjustment to the new diet.

\section{Enzyme Activities}

For the determination of enzyme activities in ruminal contents, samples were taken from various locations within the rumen as previously described 0 and $4 \mathrm{~h}$ after the $1200 \mathrm{~h}$ feeding on $\mathrm{d} 19$ and 20 . The contents were processed as described previously except that residual solids strained from whole ruminal contents were combined ( $1: 1, \mathrm{wt} / \mathrm{vol})$ with $0.9 \% \mathrm{NaOH}$, homogenized in a blender (Waring Products Division, New Hartford, CT) for $2 \mathrm{~min}$, re-strained through a PECAP polyester screen (pore size $355 \mu \mathrm{m}$ ), and mixed with the filtered ruminal fluid. Fifty milliliters of the filtered ruminal fluid was sampled. All samples were stored at $-20^{\circ} \mathrm{C}$ until analysis.

Enzyme activities in the strained ruminal fluid were determined as described by Bailey et al. (1992) and Colombatto et al. (2003a) except for the determination of protease activity. Birchwood xylan and medium-viscosity carboxymethylcellulose (Sigma Chemicals, St. Louis, MO) in $0.1 M$ citrate phosphate buffer ( $\mathrm{pH} 6.0$;
$10 \mathrm{mg} / \mathrm{mL}$ ) were used as substrates for xylanase (EC 3.2.1.8) and endoglucanase (EC 3.2.1.4) activity determination, respectively. Forty microliters of strained ruminal fluid was incubated with $1 \mathrm{~mL}$ of substrate. Incubations were performed in triplicate for $60 \mathrm{~min}$ (xylanase) or $120 \mathrm{~min}$ (endoglucanase) at $39^{\circ} \mathrm{C}$. The enzymic reaction was terminated by adding dinitrosalicylic acid reagent. The reaction contents were boiled for $15 \mathrm{~min}$ and cooled in cold water. Absorbance was read at 530 $\mathrm{nm}$ using a MRX-HD plate reader (Dynatech Laboratories, Chantilly, VA). The absorbance values were converted to reducing sugars using standard xylose or glucose curve for xylanase or endoglucanase activity, respectively, developed for 15 min of incubation. Blanks, substrate alone (i.e., no enzyme) and enzyme alone (i.e., no substrate), were also included to correct for substrate autolysis and sugars present in the enzyme sample, respectively.

Determinations of exoglucanase (EC 3.2.1.91), $\beta$-Dglucosidase (EC 3.2.1.21), $\beta$-D-xylosidase (EC 3.2.1.37), and $\alpha$-D-arabinofuranosidase (EC 3.2.1.55) activities in strained ruminal fluid were performed using stock solutions $(1 \mathrm{~m} M)$ of $p$-nitrophenyl ( $p$-NP) derivatives. Substrates, obtained from Sigma Chemicals, were $p$-NP$\beta$-D-cellobioside, $p$-NP- $\beta$-D-glucopyranoside, $p$-NP- $\beta$-Dxylopyranoside, and $p$-NP- $\alpha$-L-arabinofuranoside. Samples of strained ruminal fluid $(20 \mu \mathrm{L})$ were incubated with $80 \mu \mathrm{L}$ of corresponding substrate (prepared in 0.1 $M$ citrate phosphate buffer, $\mathrm{pH} 6.0$ ) at $39^{\circ} \mathrm{C}$ for $60 \mathrm{~min}$. The reaction was terminated by the addition of $100 \mu \mathrm{L}$ of $1 M$ glycine-NaOH buffer ( $\mathrm{pH} 10.8$ ). The release of $p$-nitrophenol was determined colorimetrically at 420 $\mathrm{nm}$. One unit of each enzyme activity was defined as the amount of enzyme required to release 1 nanomole of $p$-nitrophenol per minute per milliliter, under the conditions of the assay.

Protease activity was assayed using azocasein (lot 25H7125, Sigma Chemical) as a substrate in a similar manner as used by Brock et al. (1982). Strained ruminal fluid $(0.4 \mathrm{~mL})$ was added to $0.5 \mathrm{~mL}$ of azocasein $(2 \%$ $\mathrm{wt} / \mathrm{vol}$ ) in $0.1 M$ citrate phosphate buffer ( $\mathrm{pH}$ 6.8). Triplicate tubes were mixed and incubated for $1 \mathrm{~h}$ at $39^{\circ} \mathrm{C}$. Reactions were stopped by the addition of $0.5 \mathrm{~mL}$ of $15 \%$ (wt/vol) TCA. Background controls, in which azocasein was added after reactions were terminated with TCA, were also included. After addition of TCA, tubes were mixed, placed on ice for $30 \mathrm{~min}$, and then centrifuged at $15,600 \times \mathrm{g}$ for $5 \mathrm{~min}$ at room temperature. Supernatant $(0.75 \mathrm{~mL})$ was mixed with $0.75 \mathrm{~mL}$ of $0.5 \mathrm{M} \mathrm{NaOH}$ and absorbance was spectrophotometrically measured at $420 \mathrm{~nm}$ using an MRX-HD plate reader. Protease activity was expressed as milligrams of azocasein hydrolyzed per hour per milliliter of ruminal fluid. 
Protease activity of the enzyme product was also assayed with or without addition of specific protease inhibitors, such as $10 \mathrm{~m} M$ phenylmethylsulfonyl fluoride (an inhibitor of serine proteases), $1 \mathrm{~m} M$ chloromercuribenzoic acid (an inhibitor of cysteine proteases), and 10 $\mathrm{m} M$ disodium EDTA (an inhibitor of metalloproteases).

\section{Microbial Nitrogen Synthesis}

One kilogram of fresh rumen contents obtained from each cannulated cow during rumen evacuation on the last day of each period was blended (Waring Products Division, New Hartford, CT) with $1 \mathrm{~L}$ of $0.9 \% \mathrm{NaCl}$ for 2 min and then strained through a PECAP polyester screen (pore size, $355 \mu \mathrm{m}$ ). The filtrate was centrifuged $\left(800 \times g\right.$ for $15 \mathrm{~min}$ at $4^{\circ} \mathrm{C}$ ) to remove feed particles and then the supernatant was recentrifuged $(20,000 \times g$ for 45 min at $4^{\circ} \mathrm{C}$ ) to obtain a bacterial pellet, which was stored at $-20^{\circ} \mathrm{C}$. The bacterial pellets were freeze-dried, ground using a ball mill (Wig-L-Bug; Crescent Dental Mfg. Co., Lyons, IL), and stored for analysis of purine$\mathrm{N}$ and total-N.

Total urine collections were made from cannulated cows on d 19 to 21 using indwelling Foley catheters (26 French, 75-cc balloon; C. R. Bard, Inc., Covington, GA), which were inserted on d 19 of each experimental period; urine output was measured every $12 \mathrm{~h}$ for $3 \mathrm{~d}$. Fresh containers with $480 \mathrm{~mL}$ of $4 \mathrm{~N} \mathrm{H}_{2} \mathrm{SO}_{4}$ were attached to catheters at 1100 and $2300 \mathrm{~h}$ to obtain daily samples (final $\mathrm{pH}<3$ ). After the weight of the acidified urine was recorded, 2 sets of $3-\mathrm{mL}$ aliquots were taken, diluted to $15 \mathrm{~mL}$ with distilled water, and stored at $-20^{\circ} \mathrm{C}$ for the analysis of allantoin and uric acid.

Total purine derivatives $(\mathbf{P D})$ excreted $(\mathrm{mmol} / \mathrm{d})$ were estimated as the sum of uric acid and allantoin. Excretion of the endogenous PD was assumed constant at $0.385 \mathrm{mmol} / \mathrm{kg}$ of $\mathrm{BW}^{0.75}$ for individual cows (Chen and Gomes, 1992). Purine absorption of microbial origin $(\mathrm{mmol} / \mathrm{d})$ was calculated as: (total PD excreted - endogenous PD)/0.85 (Chen and Gomes, 1992). Synthesis of microbial $\mathrm{N}$ within the rumen was calculated as: (purine absorption $\times 70) /($ purine-N:total $\mathrm{N}$ in mixed rumen microbes $\times 0.83 \times 1000)($ Chen and Gomes, 1992). The average purine-N:total $\mathrm{N}$ in mixed rumen microbes measured in this study was 0.209 .

\section{Chemical Analyses}

Analytical DM content of samples was determined by oven drying at $135^{\circ} \mathrm{C}$ for $3 \mathrm{~h}$; OM was determined by ashing, and $\mathrm{N}$ content was determined by a flash combustion (Carlo Erba Instruments, Milan, Italy) (AOAC, 1990). The NDF and ADF contents were sequentially determined using an $\mathrm{ANKOM}^{200 / 220}$ Fiber
Analyzer (ANKOM Technology, Fairport, NY) according to the methodology supplied by the company, which is based on the methods described by Van Soest et al. (1991). Sodium sulfite and heat-stable amylase were used in the analysis of NDF. Hemicellulose was calculated as the difference between $\mathrm{NDF}$ and ADF. Starch was determined by enzymic hydrolysis of $\alpha$ linked glucose polymers as described by Rode et al. (1999). Concentration of $\mathrm{Yb}$ was determined using atomic absorption according to the AOAC procedure (AOAC, 1990).

Ruminal VFA were separated and quantified using gas chromatography (5890; Hewlett Packard, Mississauga, Ontario, Canada) with a $30-\mathrm{m}$ (0.32-mm i.d.) column (Nukol column; Supelco, Oakville, Ontario, Canada). Concentration of $\mathrm{NH}_{3}-\mathrm{N}$ in the ruminal contents was determined as described by Rhine et al. (1998).

Allantoin in urine was determined by autoanalyzer using the procedure of Pentz (1969) with modifications by Lindberg and Jansson (1989). Uric acid was determined using a commercial kit (Sigma no. 292; Sigma Chemicals). Total-N content in the microbial pellet was determined by a flash combustion (Carlo Erba Instruments). Purine content in the microbial pellet was determined using the procedure of Zinn and Owens (1986).

\section{In Vitro Measurements}

In vitro fermentations of forages and concentrates with or without EPE were investigated upon completion of the in vivo study to assess the specificity between individual ingredients of the TMR and EPE. In vitro ruminal gas production was measured using a system similar to that described by Mauricio et al. (1999). Fresh samples of the alfalfa hay and barley silage that were fed to the cows during the in vivo experiment were chopped for $10 \mathrm{~s}$ using a Knifetec 1095 sample mill (Foss Tecator, Höganäs, Sweden). Fresh, milled alfalfa hay or barley silage (approximately $1 \mathrm{~g}$ of DM) was weighed into gas-tight serum culture vials $(125 \mathrm{~mL}$ capacity) in 8 replications. The same enzyme product as was used in the dairy cow experiment was applied at a rate of $1.25 \mu \mathrm{L} / \mathrm{g}$ of DM forage $20 \mathrm{~h}$ before inoculation with ruminal fluid. The application rate of the enzyme product was the same as that used in the in vivo experiment. Three hours later, $40 \mathrm{~mL}$ of anaerobic buffer medium, prepared as outlined by Goering and Van Soest (1970) and adjusted to $\mathrm{pH} 6.5$ using $1 \mathrm{M}$ trans-aconitic acid (Sigma Chemicals), was added, and the vials were stored at $20^{\circ} \mathrm{C}$ overnight. Ruminal fluid was obtained $4 \mathrm{~h}$ after the morning feeding $(1100 \mathrm{~h})$ from a lactating dairy cow fed a TMR composed of barley 
silage, chopped alfalfa hay, rolled corn grain, and concentrate formulated for a dairy cow in early lactation. Strained ruminal fluid collected as described earlier was transported to the laboratory in sealed, preheated containers and was kept at $39^{\circ} \mathrm{C}$ in a water bath. The inoculum was dispensed (10 $\mathrm{mL}$ per vial) into culture vials that had been warmed to $39^{\circ} \mathrm{C}$ in an incubator and flushed with oxygen-free $\mathrm{CO}_{2}$. Each vial was sealed with a 14-mm butyl rubber stopper plus aluminum crimp cap immediately after loading and incubated for $18 \mathrm{~h}$. Negative controls (ruminal fluid plus buffer alone and ruminal fluid plus buffer and enzyme product) were also incubated in 8 replications. These controls were used to correct for gas release and fermentation residues resulting directly from the inoculum. Headspace gas produced by substrate fermentation was measured at $2,4,6,8,10,12$, and $18 \mathrm{~h}$ postinoculation. The gas production was measured by inserting a 23 -gauge ( 0.6 $\mathrm{mm}$ ) needle attached to a pressure transducer (type T443A, Bailey and Mackey, Birmingham, UK) connected to a visual display (Data Track, Christchurch, UK). The transducer was then removed leaving the needle in place to permit venting. Pressure values, corrected for the amount of substrate $\mathrm{OM}$ incubated and the gas released from negative controls, were used to generate volume estimates using the quadratic equation (gas volume $=0.18+3.697 \times$ gas pressure +0.0824 $\times$ gas pressure ${ }^{2}$ ) reported by Mauricio et al. (1999).

In vitro gas production and degradation of concentrates were measured using the procedure described above with a few modifications as follows. Samples of the concentrate that had been dried at $55^{\circ} \mathrm{C}$ and ground to pass a 1-mm screen were pooled over period. Approximately $0.45 \mathrm{~g}(\mathrm{DM})$ of substrate was weighed into fermentation bottles. Amounts of anaerobic buffer medium and strained ruminal fluid added to the bottles were reduced to 18 and $4.5 \mathrm{~mL}$, respectively. At the end of the 18-h incubation, contents of the incubation bottles were transferred to dried and preweighed $50-\mathrm{mL}$ centrifuge bottles. The bottles were then centrifuged at $35,000 \times \mathrm{g}$ for $20 \mathrm{~min}$, and the supernatants discarded. Then, the bottle and its contents were dried at $55^{\circ} \mathrm{C}$ for $48 \mathrm{~h}$. The weight of the bottle and its contents was recorded, and the apparent DM degradation calculated with the correction from negative controls. The dried contents were then weighed into artificial fiber bags, and NDF and ADF degradations were determined.

\section{Statistical Analyses}

All data were statistically analyzed using the mixed model procedure in SAS (SAS Institute, 1999). Data for intake, digestibility, and milk production were analyzed with a model that included the effects of level of forage in the diet (high vs. low forage), group (noncannulated vs. cannulated cows), enzyme (without vs. with EPE), and the interaction between level of forage and enzyme. Cow, period, and cow by period by group were the terms of the random statement.

Data for VFA profiles and microbial N synthesis were analyzed with a model that included the effects of level of forage in the diet (high vs. low forage), enzyme (without vs. with EPE), and the interaction between level of forage and enzyme. Cow and period were the terms of the random statement. Data for ruminal $\mathrm{pH}, \mathrm{NH}_{3}-\mathrm{N}$ concentration, and enzyme activities in the rumen were analyzed using the model described above except that the fixed effect of time after feeding was included using the repeated option. The covariance structure that resulted in the lowest values for the Akaike's information criteria and Schwartz's Bayesian criterion was used (Littell et al., 1998).

Data for in vitro assays were analyzed with a model that included the effects of source of forage (alfalfa hay vs. barley silage) or concentrate (concentrate of HF diet vs. concentrate of LF diet), enzyme (without vs. with $\mathrm{EPE}$ ), and the interaction between source of forage or concentrate and enzyme. Replication within treatment was the term used as the random statement. Data for gas production were analyzed separately by incubation time.

Residual errors were used to test main effects and interactions. Differences were considered significant at $P<0.05$ and trends were discussed at $P<0.15$. When the interaction between level of forage in the diet and enzyme was $P<0.15$, contrasts were used to examine the effects of EPE within level of forage. Contrasts were considered significant at $P<0.05$. Results are reported as least square means.

\section{RESULTS}

\section{Enzymic Activities of the EPE}

The protease activity of the EPE was determined to be $533 \mathrm{mg}$ of azocasein hydrolyzed $/ \mathrm{mL}(\mathrm{SD}=4.4, \mathrm{n}=$ 4). In addition, the inhibitor assay showed that only one type of protease, serine protease, was present. The enzyme product contained no measurable endoglucanase, xylanase, or other fibrolytic activities.

\section{Intake and Digestibility}

The effects of adding EPE to the diet on most feed intake and digestibility variables depended upon the level of forage in the diet, as evidenced by significant interactions between enzyme and level of forage (Table 3). Generally, the effects of added EPE were most dramatic for LF diets. 
Table 3. Nutrient intake and total tract digestibility of lactating cows fed high (HF) or low forage (LF) diets without or with exogenous proteolytic enzyme (EPE) supplementation.

\begin{tabular}{|c|c|c|c|c|c|c|c|c|}
\hline \multirow[b]{3}{*}{ Item } & \multicolumn{4}{|c|}{ Diet $^{1}$} & \multirow[b]{3}{*}{$\mathrm{SE}$} & \multirow{2}{*}{\multicolumn{3}{|c|}{ Significance of effect ${ }^{2}$}} \\
\hline & \multicolumn{2}{|c|}{$\mathrm{HF}$} & \multicolumn{2}{|c|}{$\mathrm{LF}$} & & & & \\
\hline & $-\mathrm{EPE}$ & $+\mathrm{EPE}$ & $-\mathrm{EPE}$ & $+\mathrm{EPE}$ & & $\mathrm{F}$ & $\mathrm{P}$ & $\mathrm{F} \times \mathrm{P}$ \\
\hline \multicolumn{9}{|l|}{ Intake, $\mathrm{kg} / \mathrm{d}$} \\
\hline $\mathrm{DM}$ & $24.0^{\mathrm{a}}$ & $22.9^{b}$ & $27.1^{\mathrm{a}}$ & $24.5^{\mathrm{b}}$ & 0.8 & $<0.01$ & $<0.01$ & $<0.01$ \\
\hline $\mathrm{OM}$ & $22.1^{\mathrm{a}}$ & $21.1^{\mathrm{b}}$ & $25.4^{\mathrm{a}}$ & $22.6^{\mathrm{b}}$ & 0.7 & $<0.01$ & $<0.01$ & $<0.01$ \\
\hline $\mathrm{N}$ & 0.76 & 0.76 & 0.86 & 0.86 & 0.03 & $<0.01$ & $\mathrm{NS}^{3}$ & NS \\
\hline Starch & $6.71^{\mathrm{a}}$ & $6.30^{\mathrm{b}}$ & $9.82^{\mathrm{a}}$ & $7.62^{\mathrm{b}}$ & 0.35 & $<0.01$ & $<0.01$ & $<0.01$ \\
\hline $\mathrm{ADF}$ & $3.03^{\mathrm{a}}$ & $2.91^{\mathrm{b}}$ & $2.99^{\mathrm{a}}$ & $2.45^{\mathrm{b}}$ & 0.13 & $<0.01$ & $<0.01$ & $<0.01$ \\
\hline $\mathrm{NDF}$ & $6.57^{\mathrm{a}}$ & $6.11^{\mathrm{b}}$ & $6.71^{\mathrm{a}}$ & $5.93^{\mathrm{b}}$ & 0.27 & NS & $<0.01$ & 0.01 \\
\hline \multicolumn{9}{|l|}{ Digestibility, \% } \\
\hline DM & $68.9^{\mathrm{b}}$ & $70.4^{\mathrm{a}}$ & $68.0^{\mathrm{b}}$ & $75.1^{\mathrm{a}}$ & 1.3 & $<0.01$ & $<0.01$ & $<0.01$ \\
\hline $\mathrm{OM}$ & $70.2^{\mathrm{b}}$ & $71.6^{\mathrm{a}}$ & $69.2^{\mathrm{b}}$ & $75.7^{\mathrm{a}}$ & 1.3 & $<0.01$ & $<0.01$ & $<0.01$ \\
\hline $\mathrm{N}$ & $75.1^{\mathrm{b}}$ & $78.0^{\mathrm{a}}$ & $72.3^{\mathrm{b}}$ & $80.3^{\mathrm{a}}$ & 1.3 & NS & $<0.01$ & $<0.01$ \\
\hline Starch & $94.4^{\mathrm{b}}$ & $97.1^{\mathrm{a}}$ & 96.9 & 96.4 & 0.6 & $<0.01$ & $<0.01$ & $<0.01$ \\
\hline $\mathrm{ADF}$ & $24.9^{\mathrm{b}}$ & $28.1^{\mathrm{a}}$ & $21.7^{\mathrm{b}}$ & $29.5^{\mathrm{a}}$ & 3.9 & NS & $<0.01$ & $<0.01$ \\
\hline $\mathrm{NDF}$ & 40.1 & 41.6 & $39.9^{\mathrm{b}}$ & $50.2^{\mathrm{a}}$ & 3.0 & $<0.01$ & $<0.01$ & $<0.01$ \\
\hline Hemicellulose & $53.8^{\mathrm{b}}$ & $54.2^{\mathrm{a}}$ & $54.4^{\mathrm{b}}$ & $65.4^{\mathrm{a}}$ & 2.3 & $<0.01$ & $<0.01$ & $<0.01$ \\
\hline Intake of digestible $\mathrm{DM}, \mathrm{kg} / \mathrm{d}$ & 16.6 & 16.1 & 18.3 & 18.5 & 0.6 & $<0.01$ & NS & NS \\
\hline
\end{tabular}

${ }^{\mathrm{a}, \mathrm{b}}$ Means in the same row within LF and HF subgroups with different superscripts differ based on single degree of freedom contrasts $(P<0.05)$.

${ }^{1} \mathrm{HF}-\mathrm{EPE}=\mathrm{HF}$ without $\mathrm{EPE}, \mathrm{HF}+\mathrm{EPE}=\mathrm{HF}$ with $\mathrm{EPE}, \mathrm{LF}-\mathrm{EPE}=\mathrm{LF}$ without EPE, and LF+EPE $=\mathrm{LF}$ with EPE.

${ }^{2} \mathrm{~F}=$ Level of forage in the diet (high vs. low forage), $\mathrm{P}=$ proteolytic enzyme (without vs. with proteolytic enzyme), and $\mathrm{F} \times \mathrm{P}=$ interaction between $\mathrm{F}$ and $\mathrm{P}$.

${ }^{3} \mathrm{NS}=$ Nonsignificant $(P>0.15)$.

Adding EPE to the diet decreased feed intake of cows fed either LF or HF, but the negative effect of EPE on intake was greater for cows fed LF than for those fed HF. Effects of EPE addition on intake of most other nutrients (excluding N) followed a pattern similar to that of DMI. Although adding EPE to the diet decreased feed intake, total tract digestibility of DM, OM, N, ADF, and hemicellulose was increased regardless of level of forage in the diet, with greater improvements for cows fed LF diets. Digestibility of NDF was only increased due to added EPE in the case of cows fed LF diets, whereas starch digestibility was only increased for cows fed HF diets. The combined effects of EPE on intake and digestibility resulted in no change in intake of digestible DM. Increasing the level of forage in the diet decreased DMI, decreased starch intake, and increased fiber intakes as expected. Furthermore, LF diets were of higher digestibility than $\mathrm{HF}$ diets.

\section{In Vitro Gas Production and Degradability}

Gas production profiles of forages and concentrates derived from in vitro measurements are shown in Figure 1. Gas production was higher during the entire incubation period for barley silage compared with alfalfa hay. Starting at $6 \mathrm{~h}$ of incubation, the addition of EPE tended (at $6 \mathrm{~h}$ of incubation, $P=0.15$ ) to increase or increased the gas production from both forages. Be- cause the effects of EPE addition on nutrient digestibilities in the animal experiment were greater for the LF diet than the HF diet, in vitro incubation of the concentrates used in the HF or LF diets were performed with or without EPE addition. Gas production was higher during the total incubation period for the concentrate used in the LF diet than for the concentrate used in the HF diet. Starting at $6 \mathrm{~h}$ of incubation, EPE addition increased the gas production of LF concentrate, but had no effect on HF concentrate, resulting in interactions between source of concentrate and EPE. Degradabilities of DM and NDF measured after $18 \mathrm{~h}$ of incubation were higher for the LF concentrate than for the HF concentrate, and they were increased by the addition of EPE for both concentrates (Figure 2). However, degradability of ADF was not affected by source of concentrate or addition of EPE. There were no interactions between source of concentrate and EPE.

\section{Ruminal Enzymic Activities}

Adding EPE to the diet increased xylanase activity in ruminal fluid from cows fed either LF or HF diets, but the increase was greater for cows fed LF diets (Table 4). Ruminal endoglucanase activity was also increased by supplementing LF or HF diets with EPE. Protease activity was only increased in the case of LF diets. Enzyme addition had no effect on ruminal activities of 

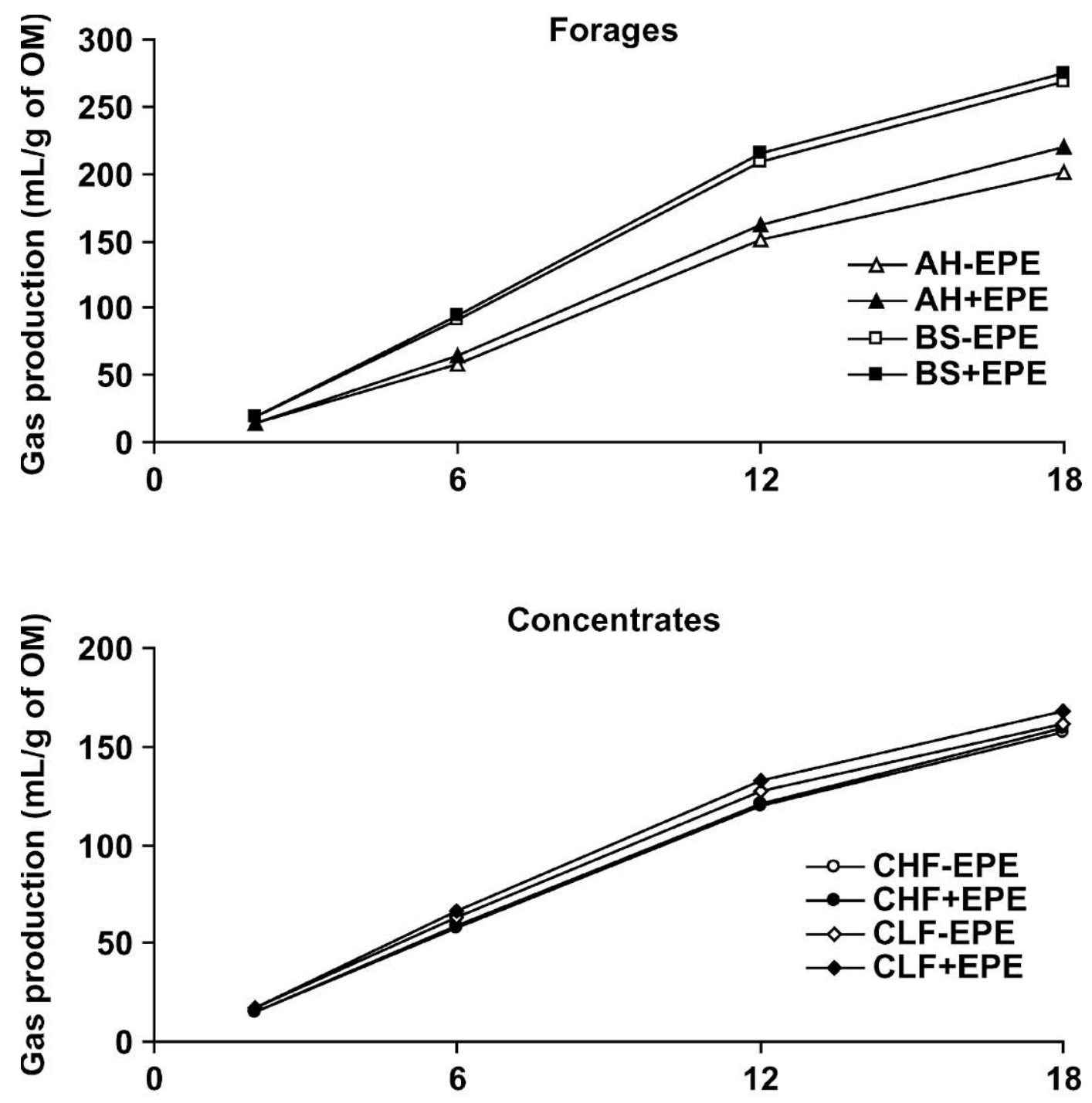

Time postinoculation (h)

Figure 1. Cumulative gas production profiles of forages (top) and concentrates (bottom) without or with exogenous proteolytic enzyme (EPE) addition for $18 \mathrm{~h}$ of incubation with ruminal fluid. Each point represents the mean of 8 and 6 observations for forages and concentrates, respectively ( $\mathrm{SE}=0.4,2.7,4.0$, and 4.7 for forages and $0.6,0.7,1.1$, and 1.5 for concentrates at 2, 6, 12, and 18 h, respectively). Top: $\mathrm{AH}-\mathrm{EPE}=$ alfalfa hay without $\mathrm{EPE}, \mathrm{AH}+\mathrm{EPE}=$ alfalfa hay with $\mathrm{EPE}, \mathrm{BS}-\mathrm{EPE}=$ barley silage without $\mathrm{EPE}$, and $\mathrm{BS}+\mathrm{EPE}=\mathrm{barley}$ silage with EPE. Bottom: CHF-EPE = concentrate used in the high forage diet without EPE, CHF+EPE = concentrate used in the high forage diet with $\mathrm{EPE}, \mathrm{CLF}-\mathrm{EPE}=$ concentrate used in the low forage diet without EPE, and CLF+EPE = concentrate used in the low forage diet with EPE.

exoglucanase, $\beta$-D-glucosidase, $\beta$-D-xylosidase, or $\alpha$-Larabinofuranosidase. Increasing the proportion of forage in the diet decreased xylanase, protease, and $\alpha$-Larabinofuranosidase activities.

\section{Milk Production and its Efficiency}

Adding EPE to the diet decreased milk yield of cows fed either LF or HF diets, but the negative effects on milk yield tended $(P=0.08)$ to be greater for cows fed
LF diets (Table 5). In fact, the decrease in milk production due to added EPE was almost 2-fold greater for cows fed LF than for those fed HF. Adding EPE to the diet had no effect on milk composition of cows fed HF diets, but EPE increased milk fat and decreased milk protein content of cows fed LF diets. The combined effects of EPE on milk yield and milk composition resulted in a higher fat yield and lower protein yield for cows fed LF+EPE than for cows fed LF-EPE. Supplemental EPE increased lactose content of milk from cows 


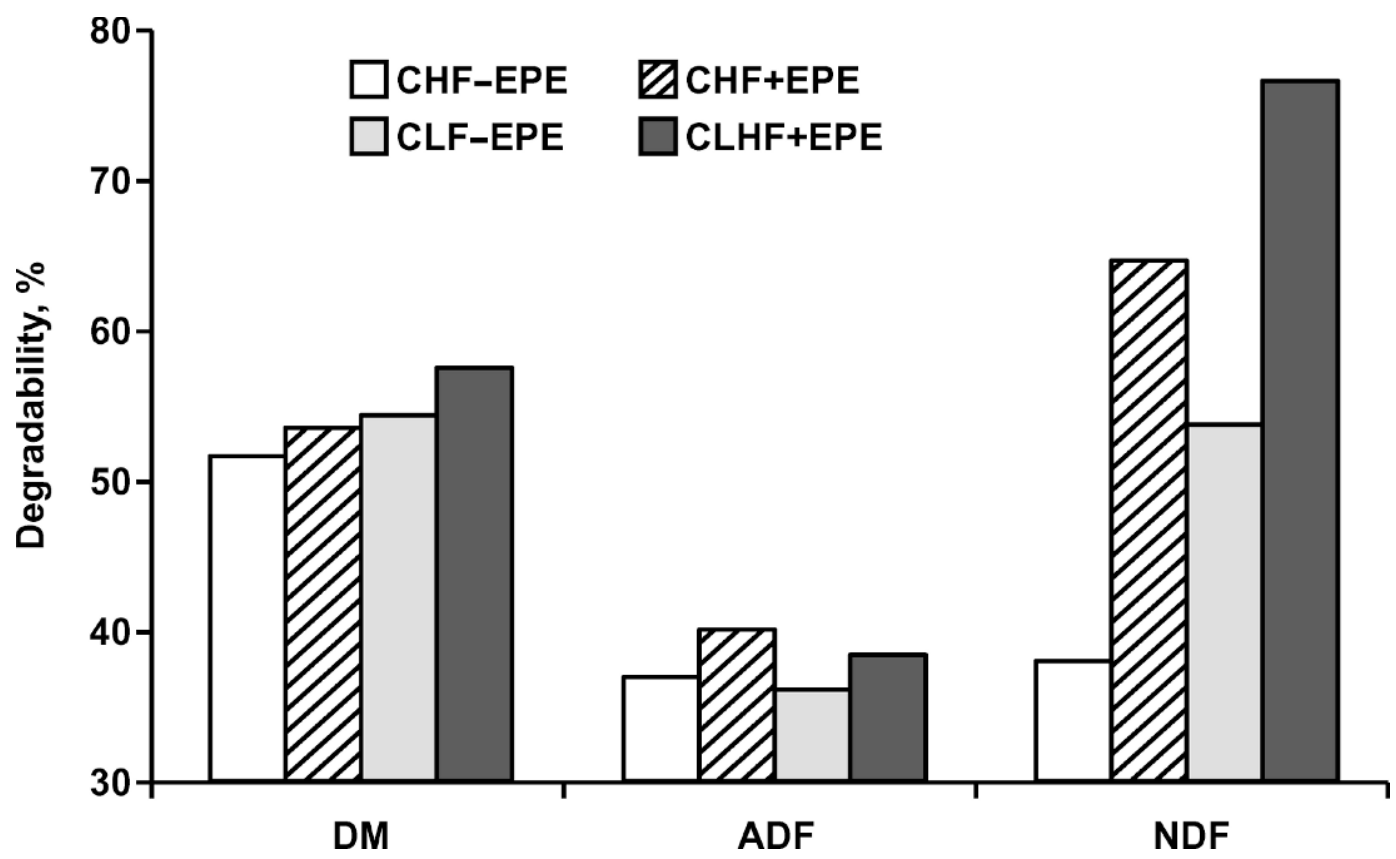

Figure 2. In vitro degradabilities of concentrates used in the high forage (HF) and low forage (LF) diets without or with exogenous proteolytic enzyme (EPE) addition after $18 \mathrm{~h}$ of incubation with ruminal fluid. CHF-EPE = Concentrate used in the HF diet without EPE, $\mathrm{CHF}+\mathrm{EPE}=$ concentrate used in the $\mathrm{HF}$ diet with $\mathrm{EPE}, \mathrm{CLF}-\mathrm{EPE}=$ concentrate used in the LF diet without $\mathrm{EPE}$, and $\mathrm{CLF}+\mathrm{EPE}=$ concentrate used in the LF diet with EPE. Each bar represents the mean of 6 observations (SE = 1.1, 2.5, and 1.9 for DM, ADF, and NDF degradability, respectively).

fed either LF or HF diets, but because of the negative effect of EPE on milk yield, lactose yield was lower for cows fed EPE than for those not receiving EPE. There was no effect of enzyme on ECM.
Added EPE increased milk production efficiency, measured either as kilograms of milk per kilogram of DMI or as kilograms of ECM per kilogram of DMI, but only in the case of cows fed an LF diet. In contrast,

Table 4. Enzymic activities in strained ruminal fluid from lactating cows fed high (HF) or low forage (LF) TMR diets without or with exogenous proteolytic enzyme (EPE) supplementation.

\begin{tabular}{|c|c|c|c|c|c|c|c|c|}
\hline \multirow[b]{3}{*}{ Activity $^{3,4}$} & \multicolumn{4}{|c|}{ Treatment $^{1}$} & \multirow[b]{3}{*}{$\mathrm{SE}$} & \multirow{2}{*}{\multicolumn{3}{|c|}{ Significance of effect ${ }^{2}$}} \\
\hline & \multicolumn{2}{|c|}{$\mathrm{HF}$} & \multicolumn{2}{|c|}{$\mathrm{LF}$} & & & & \\
\hline & $-\mathrm{EPE}$ & $+\mathrm{EPE}$ & $-\mathrm{EPE}$ & $+\mathrm{EPE}$ & & $\mathrm{F}$ & $\mathrm{P}$ & $\mathrm{F} \times \mathrm{P}$ \\
\hline $\mathrm{XY}$ & $672^{\mathrm{b}}$ & $846^{\mathrm{a}}$ & $744^{\mathrm{b}}$ & $1086^{\mathrm{a}}$ & 72 & 0.05 & 0.02 & 0.01 \\
\hline END & 296 & 460 & 368 & 480 & 63 & $\mathrm{NS}^{5}$ & $<0.01$ & NS \\
\hline EXO & 39.5 & 39.7 & 42.7 & 34.2 & 4.6 & NS & NS & NS \\
\hline GPY & 67.6 & 65.2 & 73.1 & 68.7 & 4.3 & NS & NS & NS \\
\hline XPY & 33.0 & 33.1 & 33.4 & 28.0 & 7.5 & NS & NS & NS \\
\hline PROT & 0.30 & 0.31 & $0.39^{\mathrm{b}}$ & $0.74^{\mathrm{a}}$ & 0.05 & $<0.01$ & $<0.01$ & $<0.01$ \\
\hline $\mathrm{AF}$ & 56.1 & 60.1 & 67.7 & 67.7 & 7.4 & $<0.01$ & NS & NS \\
\hline
\end{tabular}

${ }^{\mathrm{a}, \mathrm{b}}$ Means in the same row within LF and HF subgroups with different superscripts differ based on single degree of freedom contrasts $(P<0.05)$.

${ }^{1} \mathrm{HF}-\mathrm{EPE}=\mathrm{HF}$ without $\mathrm{EPE}, \mathrm{HF}+\mathrm{EPE}=\mathrm{HF}$ with $\mathrm{EPE}, \mathrm{LF}-\mathrm{EPE}=\mathrm{LF}$ without $\mathrm{EPE}$, and $\mathrm{LF}+\mathrm{EPE}=\mathrm{LF}$ with EPE.

${ }^{2} \mathrm{~F}=$ Level of forage in the diet (high vs. low forage), $\mathrm{P}=$ proteolytic enzyme (without vs. with proteolytic enzyme), and $\mathrm{F} \times \mathrm{P}=$ interaction between $\mathrm{F}$ and $\mathrm{P}$.

${ }^{3} \mathrm{XY}=\mathrm{Xylanase} ; \mathrm{END}=$ endoglucanase $; \mathrm{EXO}=$ exoglucanase $; \mathrm{GPY}=\beta$-D-glucosidase $; \mathrm{XPY}=\beta$-D-xylosidase; $\mathrm{PROT}=$ protease $; \mathrm{AF}=\alpha$-L-arabinofuranosidase.

${ }^{4} \mathrm{XY}$ and END are expressed as nanomoles of xylose or glucose per minute per milliliter; EXO, GPY, XPY, and $\mathrm{AF}$ are expressed as nanomoles of $p$-nitrophenol per minute per milliliter; PROT is expressed as azocasein hydrolyzed per hour per milliliter.

${ }^{5} \mathrm{NS}=$ Nonsignificant $(P>0.15)$. 
Table 5. Milk production and composition and efficiencies of DM and $\mathrm{N}$ use for milk production for lactating cows fed high (HF) or low forage (LF) diets without or with exogenous proteolytic enzyme (EPE) supplementation.

\begin{tabular}{|c|c|c|c|c|c|c|c|c|}
\hline \multirow[b]{3}{*}{ Item } & \multicolumn{4}{|c|}{$\operatorname{Diet}^{1}$} & \multirow[b]{3}{*}{$\mathrm{SE}$} & \multirow{2}{*}{\multicolumn{3}{|c|}{ Significance of effect ${ }^{2}$}} \\
\hline & \multicolumn{2}{|c|}{$\mathrm{HF}$} & \multicolumn{2}{|c|}{$\mathrm{LF}$} & & & & \\
\hline & -EPE & $+\mathrm{EPE}$ & $-\mathrm{EPE}$ & $+\mathrm{EPE}$ & & $\mathrm{F}$ & $\mathrm{P}$ & $\mathrm{F} \times \mathrm{P}$ \\
\hline \multicolumn{9}{|l|}{ Yield, kg/d } \\
\hline Milk & $42.8^{\mathrm{a}}$ & $41.4^{\mathrm{b}}$ & $48.1^{\mathrm{a}}$ & $45.4^{\mathrm{b}}$ & 2.2 & $<0.01$ & $<0.01$ & 0.08 \\
\hline $\mathrm{ECM}^{3}$ & 37.2 & 36.5 & 37.4 & 37.4 & 2.0 & $\mathrm{NS}^{5}$ & NS & NS \\
\hline Fat & 1.43 & 1.38 & $1.16^{\mathrm{b}}$ & $1.28^{\mathrm{a}}$ & 0.11 & $<0.01$ & NS & 0.02 \\
\hline Protein & 1.22 & 1.20 & $1.46^{\mathrm{a}}$ & $1.33^{\mathrm{b}}$ & 0.05 & $<0.01$ & $<0.01$ & $<0.01$ \\
\hline Lactose & 1.99 & 1.92 & 2.27 & 2.19 & 0.11 & $<0.01$ & 0.02 & NS \\
\hline \multicolumn{9}{|c|}{ Component content, $\%$} \\
\hline Fat & 3.34 & 3.31 & $2.39^{\mathrm{b}}$ & $2.83^{\mathrm{a}}$ & 0.19 & $<0.01$ & 0.01 & $<0.01$ \\
\hline Protein & 2.87 & 2.94 & $3.09^{\mathrm{a}}$ & $2.95^{\mathrm{b}}$ & 0.10 & $<0.01$ & NS & $<0.01$ \\
\hline Lactose & 4.61 & 4.69 & 4.77 & 4.80 & 0.04 & $<0.01$ & $<0.01$ & NS \\
\hline \multicolumn{9}{|l|}{ Efficiency } \\
\hline Milk/DMI & 1.79 & 1.81 & $1.78^{\mathrm{b}}$ & $1.86^{\mathrm{a}}$ & 0.10 & NS & $<0.01$ & 0.07 \\
\hline ECM/DMI & 1.58 & 1.57 & $1.39^{\mathrm{b}}$ & $1.54^{\mathrm{a}}$ & 0.08 & $<0.01$ & 0.02 & 0.01 \\
\hline Milk N/N intake ${ }^{4}$ & $0.26^{\mathrm{a}}$ & $0.25^{\mathrm{b}}$ & $0.27^{\mathrm{a}}$ & $0.24^{\mathrm{b}}$ & 0.01 & NS & $<0.01$ & 0.11 \\
\hline MUN, mg/dL & 15.6 & 15.9 & 15.4 & 15.4 & 0.6 & NS & NS & NS \\
\hline
\end{tabular}

${ }^{\mathrm{a}, \mathrm{b}}$ Means in the same row within LF and HF subgroups with different superscripts differ based on single degree of freedom contrasts $(P<0.05)$.

${ }^{1} \mathrm{HF}-\mathrm{EPE}=\mathrm{HF}$ without $\mathrm{EPE}, \mathrm{HF}+\mathrm{EPE}=\mathrm{HF}$ with EPE, LF-EPE $=\mathrm{LF}$ without EPE, and LF $+\mathrm{EPE}=\mathrm{LF}$ with EPE.

${ }^{2} \mathrm{~F}=$ Level of forage in the diet (high vs. low forage), $\mathrm{P}=$ proteolytic enzyme (without vs. with proteolytic enzyme), and $\mathrm{F} \times \mathrm{P}=$ interaction between $\mathrm{F}$ and $\mathrm{P}$.

${ }^{3} \mathrm{ECM}=$ Energy-corrected milk.

${ }^{4}$ Efficiency of use of feed $\mathrm{N}$ to milk $\mathrm{N}=$ (total milk protein, $\left.\mathrm{kg} / \mathrm{d} \div 6.38\right) \div \mathrm{N}$ intake, $\mathrm{kg} / \mathrm{d}$.

${ }^{5} \mathrm{NS}=$ Nonsignificant $(P>0.15)$.

efficiency of $\mathrm{N}$ use was decreased with added EPE for cows fed $\mathrm{LF}$ or $\mathrm{HF}$, with a trend $(P=0.11)$ for greater reduction in efficiency of $\mathrm{N}$ use for cows fed LF. Despite the reduction in $\mathrm{N}$ use due to EPE, MUN levels in milk were not affected by diet.

As expected, increasing the proportion of forage in the diet decreased milk yield, increased fat content, decreased protein content, and decreased lactose content. Consequently, fat yield increased, whereas protein and lactose yields decreased when HF diets were fed instead of LF diets. Increasing the forage level in the diet had no effect on milk production efficiency measured as kilograms of milk per kilogram of DMI, but increased milk production efficiency measured as kilograms of ECM per kilogram of DMI. Efficiency of N use was not affected by forage level in the diet.

\section{Ruminal Fermentation, Rumen Contents, and Microbial Yield}

Adding EPE to the diet decreased mean ruminal $\mathrm{pH}$ but only in the case of cows fed the LF diet (Table 6). Ruminal $\mathrm{pH}$ decreased after feeding for all diets as expected, and there was no interaction between time and treatment. Enzyme supplementation had no effect on total VFA concentration, but it reduced the propor- tion of acetate in ruminal fluid from cows fed HF diets, and reduced the concentration of butyrate for cows fed LF diets. Other individual VFA were not affected by enzyme supplementation. The ratios of acetate to propionate and acetate plus butyrate to propionate were not affected by EPE addition to the diet. Adding EPE to either an LF or HF diet tended $(P=0.11)$ to increase $\mathrm{NH}_{3}-\mathrm{N}$ concentration.

Increasing the portion of forage in the diet increased ruminal $\mathrm{pH}$ as expected. Cows fed HF diets had lower total VFA concentrations compared with those fed HF diets. Molar proportions of acetate, butyrate, and isobutyrate were higher, whereas proportions of propionate were lower for cows fed HF diets than for those fed LF diets. Consequently, ratios of acetate to propionate and acetate plus butyrate to propionate were also higher for cows fed HF diets than for those fed LF diets. Feeding an $\mathrm{HF}$ diet increased $\mathrm{NH}_{3}-\mathrm{N}$ concentration. There was no effect of treatment on the wet or dry weight of ruminal contents.

Addition of EPE to the diet had no effect on urinary excretion of PD or estimated microbial N supply (Table 7). In contrast, increasing the proportion of forage in the diet decreased the excretion of PD and decreased the calculated absorption of PD. However, estimated 
Table 6. Ruminal fermentation characteristics and rumen volume of lactating cows fed high (HF) or low forage (LF) diets without or with exogenous proteolytic enzyme (EPE) supplementation.

\begin{tabular}{|c|c|c|c|c|c|c|c|c|}
\hline \multirow[b]{3}{*}{ Item } & \multicolumn{4}{|c|}{$\operatorname{Diet}^{1}$} & \multirow[b]{3}{*}{$\mathrm{SE}$} & \multirow{2}{*}{\multicolumn{3}{|c|}{ Significance of effect ${ }^{2}$}} \\
\hline & \multicolumn{2}{|c|}{$\mathrm{HF}$} & \multicolumn{2}{|c|}{$\mathrm{LF}$} & & & & \\
\hline & -EPE & $+\mathrm{EPE}$ & $-\mathrm{EPE}$ & $+\mathrm{EPE}$ & & $\mathrm{F}$ & $\mathrm{P}$ & $\mathrm{F} \times \mathrm{P}$ \\
\hline Mean ruminal $\mathrm{pH}$ & 5.95 & 6.00 & $5.60^{\mathrm{a}}$ & $5.50^{\mathrm{b}}$ & 0.05 & $<0.01$ & $\mathrm{NS}^{3}$ & $<0.01$ \\
\hline Total VFA, mM & 114.9 & 110.0 & 129.4 & 138.2 & 7.4 & $<0.01$ & NS & NS \\
\hline \multicolumn{9}{|l|}{ Individual VFA, mol/100 mol } \\
\hline Acetate (A) & $63.4^{\mathrm{a}}$ & $61.1^{\mathrm{b}}$ & 54.3 & 54.8 & 1.7 & $<0.01$ & NS & 0.09 \\
\hline Propionate (P) & 20.3 & 21.9 & 30.8 & 31.9 & 2.2 & $<0.01$ & NS & NS \\
\hline Butyrate (B) & 12.0 & 12.6 & $11.6^{\mathrm{a}}$ & $9.8^{\mathrm{b}}$ & 0.9 & $<0.01$ & NS & 0.02 \\
\hline Valerate & 1.59 & 1.69 & 1.70 & 1.57 & 0.08 & NS & NS & NS \\
\hline Isobutyrate & 0.81 & 0.85 & 0.56 & 0.65 & 0.07 & $<0.01$ & NS & NS \\
\hline Isovalerate & 1.42 & 1.48 & 0.91 & 0.99 & 0.13 & $<0.01$ & NS & NS \\
\hline A:P & 3.11 & 2.89 & 1.86 & 1.82 & 0.23 & $<0.01$ & NS & NS \\
\hline$(A+B): P$ & 3.69 & 3.47 & 2.26 & 2.16 & 0.27 & $<0.01$ & NS & NS \\
\hline $\mathrm{NH}_{3}-\mathrm{N}, \mathrm{mg} / \mathrm{dL}$ & 14.5 & 17.2 & 10.4 & 13.1 & 1.9 & 0.02 & 0.11 & NS \\
\hline \multicolumn{9}{|l|}{ Whole ruminal contents } \\
\hline Wet, kg & 92.8 & 83.6 & 86.0 & 80.3 & 8.1 & NS & NS & NS \\
\hline $\mathrm{DM}, \mathrm{kg}$ & 13.2 & 11.8 & 12.6 & 11.5 & 0.9 & NS & NS & NS \\
\hline
\end{tabular}

${ }^{a, b}$ Means in the same row within LF and HF subgroups with different superscripts differ based on single degree of freedom contrasts $(P<0.05)$.

${ }^{1} \mathrm{HF}-\mathrm{EPE}=\mathrm{HF}$ without $\mathrm{EPE}, \mathrm{HF}+\mathrm{EPE}=\mathrm{HF}$ with $\mathrm{EPE}, \mathrm{LF}-\mathrm{EPE}=\mathrm{LF}$ without $\mathrm{EPE}$, and $\mathrm{LF}+\mathrm{EPE}=\mathrm{LF}$ with EPE.

${ }^{2} \mathrm{~F}=$ Level of forage in the diet (high vs. low forage), $\mathrm{P}=$ proteolytic enzyme (without vs. with proteolytic enzyme), and $\mathrm{F} \times \mathrm{P}=$ interaction between $\mathrm{F}$ and $\mathrm{P}$.

${ }^{3} \mathrm{NS}=$ Nonsignificant $(P>0.15)$.

microbial $\mathrm{N}$ supply was not affected by proportion of forage in the diet.

\section{DISCUSSION}

The protease product used in this study was evaluated previously in vitro by our group and the positive results obtained led us to conduct the present in vivo study. Using batch culture, we observed that when this enzyme product (formerly denoted as RT1184) was ap- plied to alfalfa hay at a similar rate $(1.5 \mathrm{mg} / \mathrm{g}$ of $\mathrm{DM}$ alfalfa hay) as was applied to TMR in the present study, DM degradation at $18 \mathrm{~h}$ was improved by $9.8 \%$ (Colombatto et al., 2003b). In continuous culture, adding this enzyme product to a TMR at a similar rate (1.5 $\mathrm{mg} / \mathrm{g}$ of DM TMR) as was used in the present study increased NDF degradability by 25 to $43 \%$, depending upon the $\mathrm{pH}$ at which the cultures were maintained (Colombatto et al., 2003a). Thus, the improvements in in vivo DM and NDF digestibility observed in the pres-

Table 7. Urinary purine derivative excretion and microbial $\mathrm{N}$ synthesis for lactating cows fed high (HF) or low forage (LF) TMR diets without or with exogenous proteolytic enzyme (EPE) supplementation.

\begin{tabular}{|c|c|c|c|c|c|c|c|c|}
\hline \multirow[b]{3}{*}{ Item } & \multicolumn{4}{|c|}{$\operatorname{Diet}^{1}$} & \multirow[b]{3}{*}{$\mathrm{SE}$} & & & \\
\hline & \multicolumn{2}{|c|}{$\mathrm{HF}$} & \multicolumn{2}{|c|}{$\mathrm{LF}$} & & \multicolumn{3}{|c|}{ Significance of effect ${ }^{2}$} \\
\hline & $-\mathrm{EPE}$ & $+\mathrm{EPE}$ & $-\mathrm{EPE}$ & $+\mathrm{EPE}$ & & $\mathrm{F}$ & $\mathrm{P}$ & $\mathrm{F} \times \mathrm{P}$ \\
\hline \multicolumn{9}{|l|}{ Urinary excretion, $\mathrm{mmol} / \mathrm{d}$} \\
\hline Uric acid & 46.2 & 40.5 & 55.7 & 52.7 & 4.0 & $<0.01$ & $\mathrm{NS}^{4}$ & NS \\
\hline Allantoin & 324 & 290 & 368 & 392 & 32 & $<0.01$ & NS & NS \\
\hline Total & 371 & 329 & 421 & 443 & 34 & $<0.01$ & NS & NS \\
\hline Absorption, ${ }^{3} \mathrm{mmol} / \mathrm{d}$ & 437 & 390 & 499 & 525 & 43 & 0.04 & NS & NS \\
\hline Microbial N supply, ${ }^{3} \mathrm{~g} / \mathrm{d}$ & 196 & 161 & 194 & 204 & 20 & NS & NS & NS \\
\hline
\end{tabular}

${ }^{1} \mathrm{HF}-\mathrm{EPE}=\mathrm{HF}$ without $\mathrm{EPE}, \mathrm{HF}+\mathrm{EPE}=\mathrm{HF}$ with $\mathrm{EPE}, \mathrm{LF}-\mathrm{EPE}=\mathrm{LF}$ without $\mathrm{EPE}$, and $\mathrm{LF}+\mathrm{EPE}=\mathrm{LF}$ with EPE.

${ }^{2} \mathrm{~F}=$ Level of forage in the diet (high vs. low forage), $\mathrm{P}=$ proteolytic enzyme (without vs. with proteolytic enzyme), and $\mathrm{F} \times \mathrm{P}=$ interaction between $\mathrm{F}$ and $\mathrm{P}$.

${ }^{3}$ Calculated based on equation from Chen and Gomes (1992).

${ }^{4} \mathrm{NS}=$ Nonsignificant $(P>0.15)$. 
ent study were consistent with effects observed previously in vitro. When added to the diet of dairy cows, EPE resulted in considerable increases in digestibilities of most nutrients particularly when used with the LF diet, with improvements ranging from $11.1 \%$ ( $\mathrm{N}$ digestibility) to $35.2 \%$ (ADF digestibility). These results confirm the validity of in vitro techniques for screening the effects of exogenous enzymes on digestibility (Colombatto and Beauchemin, 2003).

Even though the enzyme product used in this study contained no measurable fibrolytic activity, sizable increases in $\mathrm{ADF}, \mathrm{NDF}$, and hemicellulose digestibility were noted, particularly in cows fed the LF diet. The mode of action whereby total tract digestion of the TMR increased due to added EPE is uncertain. A portion of the increase in digestibility may have resulted from the reduction in intake that occurred. It is well documented that digestibility of the diet increases with decreasing intake (NRC, 2001). Based on NRC (2001) estimated discounts, reduced intake due to enzyme supplementation would have accounted for a 0.4-percentage unit increase in DM digestibility for $\mathrm{HF}$ diets and a 1.9percentage unit increase for LF diets. Thus, the true effect of EPE supplementation on DM digestibility may have been negligible for HF diets, but for LF diets, a $7.6 \%$ improvement in DM digestibility could be attributed to the direct effect of enzyme addition.

Other than changes in DMI, the mechanism whereby EPE improved digestibility is unclear. In a recent review, Beauchemin et al. (2004) indicated that the mode of action of exogenous enzymes is complex, with evidence for various interdependent effects. In the present study, adding EPE to the diet increased ruminal xylanase and endoglucanase activities. Because the enzyme supplement contained no fibrolytic activities, increased enzymic activity of ruminal fluid indicates a possible stimulation of rumen microbial populations or synergistic effects with hydrolases of ruminal microorganisms. Increased enzymic activity within the rumen may have contributed to the observed enhanced total tract digestibility of the diet fed. Synergistic effects have been reported previously with enzyme supplementation (Morgavi et al., 2000). Another possibility is that EPE helped remove structural cell wall proteins and allowed faster microbial access to degradable fiber (Nsereko et al., 2000; Colombatto et al., 2003a). Further research on the mode of action of feed enzymes is needed to understand how enzymes, particularly protease enzymes, can increase digestibility of the diet, including the fiber fraction.

The in vitro phase of this study was done to help understand the effects of added enzyme on feed digestibility, and in particular, the greater improvements in digestibility observed in vivo for the LF diet compared with the HF diet. Response to EPE addition ranged from 7.9 to $9.0 \%$ and from 2.5 to $3.0 \%$ for the last $12 \mathrm{~h}$ of incubation with alfalfa hay and barley silage, respectively. Although EPE improved the in vitro digestion of both forages, EPE was more effective for alfalfa hay than barley silage. Different response to EPE among forages was reported previously by Colombatto et al. (2003b) who reported that this product was effective when used with alfalfa hay, but not when used with corn silage. Furthermore, McGinn et al. (2004) reported no effect of this product on total tract digestibility or intake when fed to beef cattle receiving a diet containing $75 \%$ barley silage (DM basis). Therefore, it seems possible that the higher proportion of barley silage in the HF diet compared with the LF diet (44.5 vs. $18.2 \%$, DM basis) would have diminished the efficacy of EPE, resulting in less increase in nutrient digestibilities due to EPE addition.

Improvements in digestibility observed for the LF diet were apparently not solely the result of improved forage digestion. In vitro results indicate that EPE was also effective in improving the digestibility of concentrate, particularly the concentrate used in the LF diet. Differences in the effectiveness of EPE for the 2 concentrates may relate to their composition; the LF concentrate contained more barley than the HF concentrate. These results indicate that the enzyme product used in this study may be particularly effective in improving digestion of barley grain. Thus, the lower proportion of barley silage and the higher proportion of barley-based concentrate in the LF diet may account for the more effective result of adding EPE to the LF diet than adding EPE to the HF diet.

The negative impact of EPE addition on DMI was unexpected, highlighting the weaknesses of in vitro screening techniques that assume no effects of enzymes on intake. The mechanism whereby EPE addition decreased DMI is difficult to explain. In the case of cows fed LF diets, in which improvements in digestibility due to EPE were greatest, it is probable that at least some of the decrease in intake of cows fed EPE was related to increased ruminal acidosis, as evidenced by lower ruminal $\mathrm{pH}$. Lower ruminal $\mathrm{pH}$ likely resulted from the increased fiber digestibility. However, ruminal $\mathrm{pH}$ was not lowered due to EPE for cows fed HF. Thus, for cows fed HF diets, the decrease in intake could not be attributed to increased acidosis. One possibility may be the effects of the nonenzymatic compounds of the product, such as stabilizers. Another possibility is that shifts in energy metabolism due to increased feed digestibility may have contributed to the downward regulation of intake of cows fed EPE, resulting in similar digestible intake for cows fed diets with or without EPE. 
The drop in milk production observed when EPE was added to the diet, was likely the result of the decline in intake. Although milk yield decreased when EPE was added to both the HF and LF diets, dairy efficiency expressed as milk/DMI or ECM/DMI increased for the $\mathrm{LF}+\mathrm{EPE}$ diet due to increased nutrient digestibility. Dairy efficiency is a measure of the ability of the cow to convert feed to milk. Improved feed digestibility is related to increased dairy efficiency, whereas greater DMI is associated with low dairy efficiency (Britt et al., 2003).

Addition of EPE lowered milk protein percentage of cows fed LF diets, although no effects of EPE on microbial N supply were observed. The microbial N supply averaged $189 \mathrm{~g} / \mathrm{d}$, which is similar to our previous findings (Bowman et al., 2002). There was an increase in total tract $\mathrm{N}$ digestibility as a result of adding EPE to $\mathrm{LF}$ and HF diets, which may have been due to increased ruminal degradability of feed $\mathrm{N}$. If ruminal degradability of feed $\mathrm{N}$ was increased without a compensatory increase in microbial protein synthesis, it is possible that EPE resulted in reduced levels of metabolizable protein and absorbed amino acids for the synthesis of milk protein, compromising feed $\mathrm{N}$ use for milk protein $\mathrm{N}$. An imbalance between RUP and RDP may have caused the decline in milk protein percentage for cows fed LF+EPE. Increased degradation of CP in the rumen due to the addition of EPE is supported by the increased protease activity in ruminal fluid from cows fed $\mathrm{LF}+\mathrm{EPE}$. Adding EPE to the $\mathrm{LF}$ diet increased $\mathrm{NH}_{3}-\mathrm{N}$ concentration; a further indication that feed $\mathrm{N}$ degradability was increased with EPE addition. Although we formulated the diets to provide sufficient metabolizable protein for cows producing milk containing 3.3\% CP, the addition of EPE may have reduced the contribution of RUP to the metabolizable protein pool.

The effects of increasing the forage proportion of the diet observed in this study were as expected based on previous literature (Yang et al., 2001). The discussion of these effects is limited as the focus of this study was to understand the interaction between enzyme addition and level of forage in the diet, rather than the effects of forage-to-concentrate ratio, per se.

\section{CONCLUSIONS}

Adding a commercial protease enzyme product to the diets of dairy cows improved total tract digestibility, particularly in the case of low forage diets. Enzymes improved the degradation of forage, particularly that of alfalfa, and improved fiber degradability of concentrates containing barley grain. However, negative impacts of EPE on feed intake offset the benefits of improved digestibility, so intake of digestible DM was not improved using a proteolytic feed enzyme. Increased feed digestion due to enzyme supplementation was associated with increased risk of ruminal acidosis, which may have partly caused the negative effects on feed intake. Adding EPE to the diets of dairy cows increased ruminal fibrolytic enzymic activities, reinforcing the notion that exogenous enzymes act synergistically with the rumen microflora resulting in an overall improvement in feed digestion. Increased feed digestibility corresponded to improved dairy efficiency of cows fed a low forage diet, but efficiency of $\mathrm{N}$ use was decreased. Although EPE supplementation improved fiber digestion, $\mathrm{N}$ digestibility was also increased, indicating a need to augment the RUP fraction of the diet to ensure an adequate supply of metabolizable protein for milk protein synthesis.

\section{ACKNOWLEDGMENTS}

The postdoctoral fellowship for J.-S. Eun was provided for by the Natural Science and Engineering Research Council of Canada (NSERC). The authors wish to thank the crew at the Dairy Research Unit of the Lethbridge Research Centre for caring for the cows and for collecting the milk samples. Technical assistance provided by B. Farr, K. Andrews, K. Koenig, W. Yang, A. Furtado, D. Vedres, S.-H. Hong, M. Forouzmand, and R. Wuerfel during the collection period and sample analysis is sincerely appreciated.

\section{REFERENCES}

Association of Official Analytical Chemists. 1990. Official Methods of Analysis. AOAC, Arlington, VA.

Bailey, M. J., P. Biely, and K. Poutanen. 1992. Interlaboratory testing of methods for assay of xylanase activity. J. Biotechnol. 23:257-270.

Beauchemin, K. A., D. Colombatto, D. P. Morgavi, W. Z. Yang, and L. M. Rode. 2004. Mode of action of exogenous cell wall degrading enzymes for ruminants. Can. J. Anim. Sci. 84:13-22.

Bowman, G. R., K. A. Beauchemin, and J. A. Shelford. 2002. The proportion of the diet to which fibrolytic enzymes are added affects nutrient digestion by lactating dairy cows. J. Dairy Sci. 85:3420-3429.

Britt, J. S., R. C. Thomas, N. C. Speer, and M. B. Hall. 2003. Efficiency of converting nutrient dry matter to milk in Holstein herds. J. Dairy Sci. 86:3796-3801.

Brock, F. M., C. W. Forsberg, and J. G. Buchanan-Smith. 1982. Proteolytic activity of rumen microorganisms and effects of proteinase inhibitors. Appl. Environ. Microbiol. 44:561-569.

Chen, X. B., and M. J. Gomes. 1992. Estimation of microbial protein supply to sheep and cattle based on urinary excretion of purine derivatives-An overview of the technical details. Rowett Research Institute, Bucksburn, Aberdeen, UK.

Colombatto, D., and K. A. Beauchemin. 2003. A proposed methodology to standardize the determination of enzymic activities present in enzyme additives used in ruminant diets. Can. J. Anim. Sci. 83:559-568.

Colombatto, D., G. Hervás, W. Z. Yang, and K. A. Beauchemin. 2003a. Effects of enzyme supplementation of a total mixed ration on microbial fermentation in continuous culture, maintained at high and low pH. J. Anim. Sci. 81:2617-2627. 
Colombatto, D., D. P. Morgavi, A. F. Furtado, and K. A. Beauchemin. 2003b. Screening of exogenous enzymes for ruminant diet: Relationship between biochemical characteristics and in vitro ruminal degradation. J. Anim. Sci. 81:2628-2638.

Fontes, C. M. G. A., J. Hall, B. H. Hirst, G. P. Hazlewood, and H. J. Gilbert. 1995. The resistance of cellulases and xylanases to proteolytic inactivation. Appl. Microbiol. Biotechnol. 43:52-57.

Goering, H. K., and P. J. Van Soest. 1970. Forage Fiber Analyses (Apparatus, Reagents, Procedures, and Some Applications). Agric. Handbook No 379. ARS-USDA, Washington, DC.

Lindberg, J. E., and C. Jansson. 1989. A rapid automated analysis of allantoin in ruminant urine. Swed. J. Agric. Res. 19:163-168.

Littell, R. C., P. R. Henry, and C. B. Ammerman. 1998. Statistical analysis of repeated measures data using SAS procedures. J. Anim. Sci. 76:1216-1231.

Mauricio, R. M., F. L. Mould, M. S. Dhanoa, E. Owen, K. S. Channa, and M. K. Theodorou. 1999. A semi-automated in vitro gas production technique for ruminant feedstuff evaluation. Anim. Feed Sci. Technol. 79:321-330.

McGinn, S. M., K. A. Beauchemin, T. Coates, and D. Colombatto. 2004. Methane emission from beef cattle: Effects of monensin, sunflower oil, enzymes, yeast, and fumaric acid. J. Anim. Sci. 82:3346-3356.

Morgavi, D. P., K. A. Beauchemin, V. L. Nsereko, L. M. Rode, A. D. Iwaasa, W. Z. Yang, T. A. McAllister, and Y. Wang. 2000. Synergy between ruminal fibrolytic enzymes and enzymes from Trichoderma longibrachiatum. J. Dairy Sci. 83:1310-1321.

National Research Council. 2001. Nutrient Requirements of Dairy Cattle. 7th rev. ed. Natl. Acad. Sci., Washington, DC.
Nsereko, V. L., D. P. Morgavi, K. A. Beauchemin, and L. M. Rode. 2000. Inhibition of ruminant feed enzyme polysaccharidase activities by extracts from silages. Can. J. Anim. Sci. 80:523-526.

Pentz, E. I. 1969. Adaptation of the Rimini-Schryver reaction for the measurement of allantoin in urine to the autoanalyzer: Allantoin and taurine excretion following neutron irradiation. Anal. Biochem. 27:333-342.

Rhine, E. D., G. K. Sims, R. L. Mulvaney, and E. J. Pratt. 1998 Improving the Bertholot reaction for determining ammonium in soil extracts and water. Soil Sci. Soc. Am. J. 62:473-480.

Rode, L. M., W. Z. Yang, and K. A. Beauchemin. 1999. Fibrolytic enzyme supplementations for dairy cows in early lactation. J. Dairy Sci. 82:2121-2126.

SAS Institute. 1999. SAS User's Guide: Statistics (Release 8.01). SAS Inst. Inc., Cary, NC.

Tyrrell, H. F., and J. T. Reid. 1965. Prediction of the energy value of cow's milk. J. Dairy Sci. 48:1215-1223.

Van Soest, P. J., J. B. Robertson, and B. A. Lewis. 1991. Methods for dietary fiber, neutral detergent fiber, and non-starch polysaccharides in relation to animal nutrition. J. Dairy Sci. 74:35833597.

Yang, W. Z., K. A. Beauchemin, and L. M. Rode. 2001. Effects of grain processing, forage to concentrate ratio, and forage particle size on rumen $\mathrm{pH}$ and digestion by dairy cows. J. Dairy Sci. 84:2203-2216.

Yang, W. Z., K. A. Beauchemin, and D. D. Vedres. 2002. Effects of $\mathrm{pH}$ and fibrolytic enzymes on digestibility, bacterial protein synthesis, and fermentation in continuous culture. Anim. Feed Sci. Technol. 102:137-150.

Zinn, R. A., and F. N. Owens. 1986. A rapid procedure for purine measurements and its use for estimating net ruminal protein synthesis. Can. J. Anim. Sci. 66:157-166. 